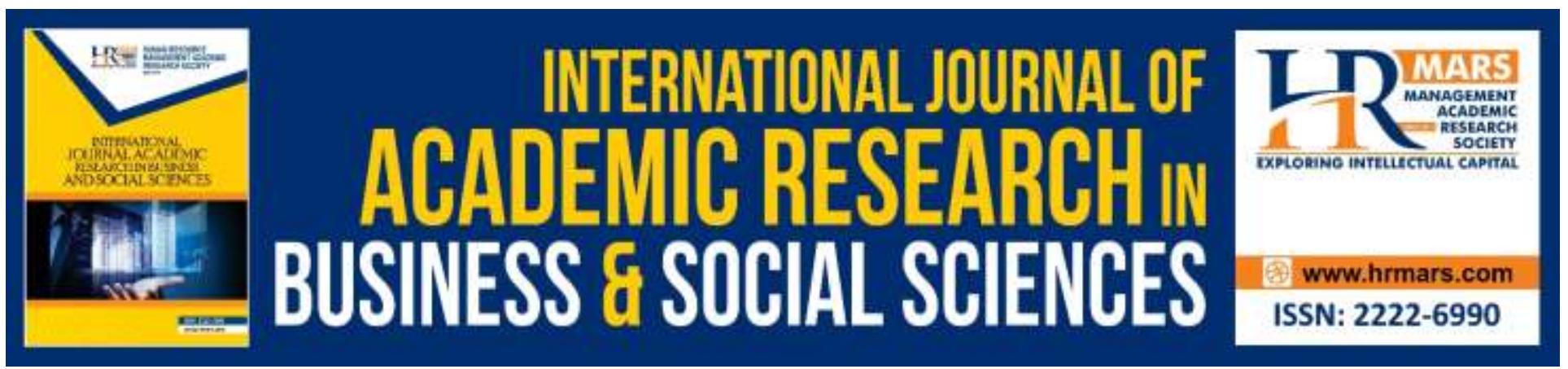

\title{
Methodology of Application of Shamanic Practice in Malay Community
}

Shazlin Abdullah and Salmah Jan Noor Muhammad

To Link this Article: http://dx.doi.org/10.6007/IJARBSS/v10-i4/7124

DOI:10.6007/IJARBSS/v10-i4/7124

Received: 02 February 2020, Revised: 01 March 2020, Accepted: 27 March 2020

Published Online: 19 April 2020

In-Text Citation: (Abdullah \& Muhammad, 2020)

To Cite this Article: Abdullah, S., \& Muhammad, S. J. N. (2020). Methodology of Application of Shamanic Practice in Malay Community. International Journal of Academic Research in Business and Social Sciences, 10(4), 254-261.

Copyright: (C) 2020 The Author(s)

Published by Human Resource Management Academic Research Society (www.hrmars.com)

This article is published under the Creative Commons Attribution (CC BY 4.0) license. Anyone may reproduce, distribute, translate and create derivative works of this article (for both commercial and non-commercial purposes), subject to full attribution to the original publication and authors. The full terms of this license may be seen

at: http://creativecommons.org/licences/by/4.0/legalcode

Vol. 10, No. 4, 2020, Pg. $254-261$

http://hrmars.com/index.php/pages/detail/IJARBSS

JOURNAL HOMEPAGE

Full Terms \& Conditions of access and use can be found at http://hrmars.com/index.php/pages/detail/publication-ethics 


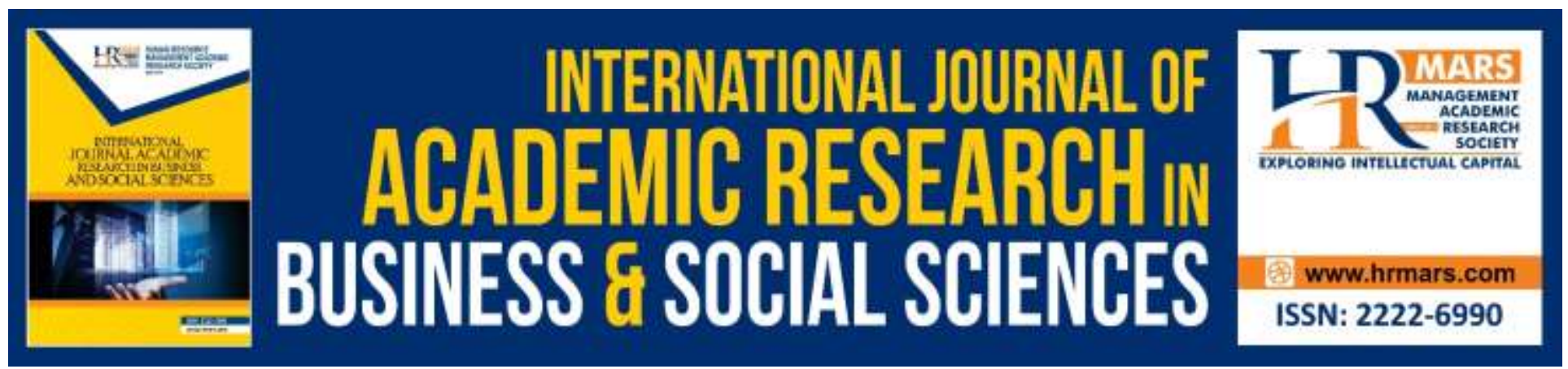

\title{
Methodology of Application of Shamanic Practice in Malay Community
}

\author{
Shazlin Abdullah and Salmah Jan Noor Muhammad \\ Faculty of Modern Languages and Communication, Universiti Putra Malaysia, 43400 UPM Serdang \\ Selangor, Malaysia
}

\begin{abstract}
Shamanism is a way of thinking with an exclusive value. The dependency of Malay society to shamans has been a symbol of their belief. The aim of this research is to identify and analyse the materials used and the methodology of application in shamanic practice by the Malay society. This research employed a qualitative methodology including library research and respondents interview. This research also solely focuses on the methodology of application in shamanic rituals among Malay society at Pantai Cahaya Bulan, Kelantan. Social Anthropology Theory explored by Koentjaraningrat has been used as a reference in this research analysis. The results showed that methodology of application of the practice involved having a flower and lime water bath ritual which is closely related to natural ingredients. Therefore, this research will provide society with knowledge about shamanic rituals that are still heavily practiced among Malay society until today.
\end{abstract}

Keywords: Shaman, Belief, Malay community, Social Anthropology Theory, Natural Ingredients

\section{Introduction}

Shamanic was a practice that began in the era of animism aimed at curing diseases and communicating with the supernatural. This belief in animism is based on the worship of the spirits and entities where they believe those spirits and entities are exist in supernatural. Humans in this age believe that nature has power and if humans do not worship nature then it is harmful to them. According to Sidek (2004), occult powers worshiped by the Malay society is to ease their difficulty in doing anything and to accomplish people's wants. According to Yusof (2003), man is the entity that cannot be seperated with the nature. In line with this belief, there is an social institution exist; shamanic institution that link the human and supernatural. This is supported by Kasimin (2006) who states that the emergence of a shaman is an intermediary between the human and the supernatural.

However, the advent of Islam to the Malaya has changed the community's belief. All this while, shamans were used as a link between the human and the supernatural by using spells but Islam had changed the society's view of the shaman as a person who can cure diseases with the permission of Allah s. w. t. According to Muhammad (2017), Malay society are open minded and easily tolerate 
with external elements. Hence, it has led to changes in the practice of shamanic after the advent of Islam. The method of the application of the shamanic practice also change in line with the changes of their belief. This can be proof by the difference between the ancient medical manuscripts of animism with the ancient medical manuscripts after the advent of Islam

There are old manuscripts that discuss traditional Malay medicine which includes the origin of a disease, the materials used, methods of treatment and a few more things. However, according to Hamid and Mohammad (2008), there was no clear written evidence that tells about the origin of traditional Malay medical practice on how they treated diseases in the past. It is very difficult for a comprehensive review of the medical knowledge of traditional Malay to be done. Therefore, this study will analyse the application of the shamanic practice in the community. This study is important because readers can learn more detail about the methods of treatment practiced by the community in line with the change of their belief.

\section{Purposes}

1. To study the method of the application of flower bath practice in Malay community.

2. To analyze the method of the application of lime bath practice in Malay community.

\section{Literature Review}

Based on the previous research, there are several researches that write about the shamanic practice. This can be seen in the study of Ar (1998), Malay believe that a person's health got two different dimensions; external dimension and internal dimension.The external dimension stated as the physical health while the internal dimension is all about spiritual. They believe that these two dimensions must be taken care of by each individual to be healthy. A better health is guaranteed if a person follow the tips and prohibition set by the shaman.

Abdullah (2006) discusses, the belief against the power of nature can affect the Malay society's mentality. The study conducted also discuss about the practice in Malay society and the Islamic view about the practice. While Shafie (2011) also discuss about the role of shamanic institution which is not limited for certain fields. The shaman uses spells consisting of the verses of the Quran and Malay language. Hamid and Fauzi (2012) describes that the traditional Malay medical are influenced by Islam. The herbs and the recitation of the verses of Quran are use to cure diseases influenced by Islam. Assimilation of traditional Malay medical can be seen through the absorption of foreign languages especially the Arabic language.

Shafie (2016) said, the traditional Malay society is tied to the system of traditional medical and shamanic practice. This study also discusses the issues contained in some of the Tibbans. This debate consist of the question about the Tibb knowledge, medicines, forms of processing and manufacture and the use of medicines.

Saparudin, Sham and Hamjah (2014) found that the Malay community had a high level of knowledge, especially in conducting healing rituals. All the research believe that shamanism was created based on the observation and life experiences that has been passed by previous members of the society. Hence, this literature review helps in comparing an article to another. Thus, these literature reviews have led to a clearer understanding and helped researchers in filling the empty space between previous studies. 
INTERNATIONAL JOURNAL OF ACADEMIC RESEARCH IN BUSINESS AND SOCIAL SCIENCES Vol. 10, No. 4, April, 2020, E-ISSN: 2222-6990 @ 2020 HRMARS

\section{Research Methodology}

In order to carry out this study, the researcher used a qualitative study method involving data collection and respondents interview. Two respondents were identified to assist this study. The chosen respondents involved a person who are proficient in the shamanic practice. The study focused on Pantai Cahaya Bulan, Kelantan region. The theory used is the Social Anthropology theory pioneered by Koentjaraningrat. According to Koentjaraningrat, anthropology is the study of humanity which generally is to study various colours, physical shape of the community, and the resulting culture (1967). There are seven cultural elements that can be described in this theory: equipment and human life complement systems, living systems, social systems, languages, arts, knowledge systems and religious systems. Equipment and life support systems describe changes in human lifestyle, from productive systems to the shelters. A livelihood system is about dealing with food gathering economics. Language is about the development of language whether oral or written. Art describes the arts that exist in society as time went on. A social system debates about kinship systems and local living systems can influence society in maintaining trust in the shamanic institution. Whereas the system of knowledge and the religious system are related to the four components: the place of ceremony, the ceremony, the objects and the ceremonial tools and the people who perform and conduct the ceremony. The study involved community systems, arts systems, language systems, knowledge systems as well as religious and spiritual systems.

\section{Data Analysis}

\section{Methodology of application of Shamanic Practice in Malay Community}

A method of shamanic practice for Malay community has been established from generation to generation. If the rules of practice are broken, then the ritual will not work. According to Koentjaraningrat (1967: 234) the people who performed the ritual were divided into three; clergy, shamans and quack. For the application of methods in shamanic practice in Malay community, it was done by shaman. This is because, shaman is an individual who is capable of healing various diseases and also able to communicate with the supernatural. For the practices presented above, shaman is the person who are responsible for the practice.

Based on the interviews conducted with Yaacob and Ramli (2018), both respondents practiced the same method of application of shamanic practice. This can be seen when both respondents stated the same procedure and materials used during the interview session. This similarity can be correlated as both respondents are from the same region which is Pantai Cahaya Bulan, Kelantan.

According to Sulaiman (2014) methods in conducting shamanic practice in Malay community are associated with the materials used in the practice of this shamanic ritual. This is because, each practice required a main ingredient. For example, flowers are very important for the practice of flower bath rituals in the Malay community. Therefore, the methodology of application of shamanic practice in Malay society can be seen as having its own association.

\section{Methodology of Flower Bath}

The Malay community believes that a flower bath can enhance person's inner glow, restore energy, and can also dispose bad luck and the negative energy inside them. There are differences in procedures and materials used in implementing these practices, depending on the shaman who will carry out the ritual. Shaman will determine the amount of types of flowers that will be used in the 
flower bath ritual. The number of flowers are in odd numbers either five, seven or nine different types of flowers. Strong and sharp flowers should be avoided.

The flowers used will be mixed with water as well as some other fragrances. Other fragrances used are from natural sources such as kaffir lime, lime juice, screwpine leaves, and "beluru". Perfumes are also mixed into this water mixture. With the influence of Islam, the flower water baths are mixed with perfume oils.

During animism era, the water mixed with the materials will be enchanted with specific spells according to the treatment that will be performed. Shaman will diagnose the type of illness encountered by the individual and will determine the type of spell that will be read to enchant the flower water. After the advent of Islam, flower bath rituals are still continued by the Malay community. However, the spells have been changed into recitation of the holy verses of the Koran.

Prayer is an element of religious ceremony described in Social Anthropological Theory. Praying in the concept of shamanic practice are the recitation of the verses and the spells. Prayer is a form of speech that appeals to God or the power they are fear. Prayer is the recitation of the holy verses of the Quran and also the recitation of some mantras or spell performed by the shaman. It is intended to seek healing and also to dispel the supernatural forces present in the patient.

"There are few types of recital for flower bath. Firstly, recite surah al-

Fatihah three times, 'tiga 'Qul three times and 'selawat 'three times.

Then, exhale the recital into the water bath."

Yaacob: 2018

This flower bath is more effective during early morning until before Asr. This is because, the level of positive energy is very high at that time and at the same time, the energy from spirit world is weaker compared to the other times. Based on the method of application of shamanic practice in the Malay community, it can be related to the Social Anthropology Theory under the principles of the religious system, which is under the system of religious rituals. The flower bath method can be associated with the moments of the ritual discussed by Koentjaraningrat. A ritual is usually carried out during twilight hours because negative energy is very active at that time.

The following is a methodology of flower baths performed in Malay's shamanic practice by using ingredients such as flowers, lime leaves, lime, and water. Firstly, the shaman will prepare the patient's flower water bath before the bathing ritual begins. This is because, there are shamans that will soak the flowers with other ingredients overnight before the bathing ritual is carried out. Pouring of water will start on the left side of the body three times. Then the right side of the body three times and then the water will be poured all over the body until the water is finish. The water will be left to be absorbed into the body of the patient.

If the intention of having flower water bath is to remove magic spells from the body of the patient, he or she will feel cold and tremble during the bathing ritual. If the intention is to enhance inner glow and retain its beauty, then the flower water scent will be stuck to the body of the patient for a long time. After bathing ritual, the rest of the flower bath can't be swept by the patient. This is because, the treatment is said to be ineffective because the rest of the bath is likened to negative energy and the bad things that have been removed from the patient's body. Therefore, the shaman will ask the closest family member to sweep the rest of the bath water. 


\section{Methodology of Lime Bath}

This lime bath ritual is a practice that has been carried out from generation to generation. Changes in the view of life and belief in religion which is from animism to Islam still do not affect this practice. During animism era, lime was used to banish genie from disturbing humans and in Islamic times, lime also serves as a tool to dispel the genie interference in human life.

Lime whether kaffir lime or key lime is used in lime bath rituals by the Malay community. Lime juice is only effective in removing genie and negative energy from the human body. This is because, the lime water has a high acid concentration. According to Sulaiman (2014) genie has the same mass as human beings. Immersion of matter with mass in lime water will crumble the said mass. Therefore, the use of lime water is believed to be a powerful tool in fighting genie disturbances in human life.

The lime bath rituals methodology practiced during animism and Islamic period did not change much. This can be seen when only the spell is changed but the main ingredient is still the same. During the animism period, enchantments on lime and lime juice were spells. Meanwhile, in Islamic times the enchantments have changed to the recitations quoted from the holy verses of the Koran.

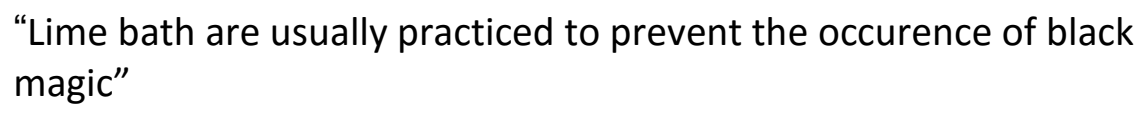

Ramli: 2018

Method of application of lime bath ritual in the Malay community starts with the amount of lime juice in the prescribed amount. Usually, the shaman will ask the patient to provide the lime. The limes were squeezed and mixed with water in a bucket. During squeezing of the lime, medical practitioners will read specific verses such as reading al-Fatihah, ayatul Qursi and salawat. There are also practitioners who read sura Yassin to the water mixture.

According to the respondents interviewed, there are also shamans or Islamic medical practitioners who mix the bath water with salt. The objective is to further enhance the acid content of the water. First of all, the patient will bathe in regular bath water and then bathe with lime water.

During the bathing ritual, the water was poured more to the back of the neck and shoulder. The lime that was found in the water is taken and applied to the joints of the body. This is because, genie or supernatural creatures love to be around the human joints. If after the bathing ritual the patient felt dizzy, vomited and burped endlessly, it indicates that the genies were trying to get out of the body.

After the lime water bath ritual, the rags used by the patient should be removed by dropping it down and the cloth should not be removed from the top. The ingredients used in the bath water should be recovered and the waste should be disposed in the river or at a location which the water is flowing because shamans and Muslim practitioners believed that genies come out through those materials.

Patients should not wipe their body after the bathing ritual because the lime scent could act as the patient's deterrent from being disturbed by supernatural creatures. The lime bath methodology can remove inconvenience from the human body. However, the effects left by the genies can't be cured by the lime bathing ritual. There are some taboos for patients who undergo the flower and lime bathing rituals. The taboos are also discussed under the religious ritual system. Based on the theory behind this research, breaking the taboo is an ignorant act. This is because, every taboo has its own reason. For lime and flower water baths, the patient can't sweep the rest of the bath 
INTERNATIONAL JOURNAL OF ACADEMIC RESEARCH IN BUSINESS AND SOCIAL SCIENCES

Vol. 10, No. 4, April, 2020, E-ISSN: 2222-6990 C 2020 HRMARS

water and wipe the body after bath. This is because, the bad energy that eliminate away through those flowers or lime might get back into the patient's body. If the patient violates this taboo, then the practice is in vain.

\section{Summary}

Based on the analysis conducted on the methodology of application of shamanic practice in Malay community at Pantai Cahaya Bulan, Kelantan, it was found that the shamanic methods used by the Malay community emphasize a specific procedure which has been passed down from generation to generation. Materials used during the shamanic rituals involve beliefs, religious ritual system, religious communities, and system of values and views of life. As Malay's belief changed from animism to Islam, there several changes happen in the ritual such as the spell that consist of the verses of the Quran. Therefore, this study can help all parties, especially those involved in sociocultural studies as this study can be used as a reference to the beliefs and dependencies of the Malay community to shamans

\section{Conclusion}

In conclusion, the practice of shamanism existed in Malay society as they believe that the supernatural's power can harm them. The practice was to worship the supernatural so they did not harm and disturb the society. Each practice must be appropriate to the purpose of the practice being applied. This is to ensure that the practice is effective. However, this practice is becoming more alienated in today's society as they consider it to be an old-fashioned knowledge of social institutions and only part of customary and cultural demands. However, the Malay community should maintain this shamanic healing practices that are related to the customary and cultural so that it will not be outdated.

According to Shafri (2018: 3), the existence of government policies supported by the World Health Organization (WHO) proposes that traditional medicine and modern medicine should be adapted so that both streams can fill the empty space of the medical world today paving the way for the shamanic institution to remain in the modern world. The positive changes experienced by the customs and culture of the community, especially in the shamanic traditional knowledge are expected to open up opportunities for the community to study and discuss this field. This field of study still has a wide scope to be search and many questions arise in this research study. Therefore, this study will also help provide an explanation and open the minds of the community about the prestige of a traditional medical knowledge which was once owned by the community before. This research is also expected to attract the public to gain knowledge on the methodology of application of shamanic practice in Malay community.

\section{Corresponding Author}

Shazlin Binti Abdullah

Universiti Putra Malaysia

43400 Serdang

Selangor Darul Ehsan

Malaysia

Emil: elin.abdullah.em@gmail.com 
INTERNATIONAL JOURNAL OF ACADEMIC RESEARCH IN BUSINESS AND SOCIAL SCIENCES

Vol. 10, No. 4, April, 2020, E-ISSN: 2222-6990 @ 2020 HRMARS

\section{References}

Abdullah, S. (2006). Institusi Bomoh dalam masyarakat Melayu menurut perspektif Islam. Jurnal Pembangunan Sosial 9 (Jun), 2006, 181-203.

Ar, H. A. (1998). Amalan Tradisi Perubatan Melayu Kini. Dewan Sastera, 50-53.

Hamid, A. F., \& Mohammad, H. (2008). Manuskrip Perubatan Melayu-Islam di Fatani- Ulasan Terhadap Manuskrip Kitab Tayyib al-Ihsan fi Tibb al-Insan Karya Syeikh Ahmad al Fatani. Journal Of Al Tamaddun, 3(1), 110-127.

Hamid, A. F. A., \& Fauzi, N. W. (2012). Perubatan Melayu Tradisional: Kitab Tibb Pontianak. Jurnal Al Tamaddun Bil 7(1), 2012, 149-162.

Kasimin, A. (2016). Unsur-unsur menurun dalam persembahan teater Melayu tradisional. Kuala Lumpur: Dewan Bahasa dan Pustaka.

Koentjaraningrat. (1967). Beberapa Pokok Antropologi Sosial. Jakarta: Penerbit Dian Rakjat.

Muhammad, S. J. N. (2017). The Deterrence of Malay Government Diplomatic Relationship with Malacca, Johore and Acheh. MANU: Jurnal Pusat Penataran Ilmu dan Bahasa (PPIB) Bil 25, 107-108.

Ramli, A. (2018) Personal Interview. Nov 212018.

Saparudin, I. F., Sham, F. M., \& Hamjah, S. H. (2014). Pemahaman Konsep Histeria dalam Masyarakat Melayu. Seminar Antarabangsa Dakwah \& Etnik 2014: Dakwah \& Etnik Perspektif Multi- disiplin, 1-7.

Shafie, A. F. (2016). Mantras in Malay Traditional Healing in Kedah: An Analysis from the Perspective of the Islamic Faith. Melayu: Jurnal Antarabangsa Dunia Melayu Jilid 9 Bil. 1,

2016, 1-30.

Shafie, N. (2011). Mantera/Jampi Sistem Kepercayaan Bomoh dan Teknik Pengubatannya di Kedah. Retrieved from http://sasterarakyat-kedah.com/index.php?cid2=10\&page=2

Shafri, M. A. M. (2018). Rumah Ubat Di Pulau Penyengat. Kuala Lumpur: Akademik Jawi Malaysia

Sidek, J. (2004). Berpawang dan Bersahabat dengan Jin dari Perspektif Islam. Kuala Lumpur: Utusan Publictions \& Distributors Sdn Bhd.

Sulaiman, M. F. I. (2014). Tips Mengesan Jin dan Sihir Di Dalam Badan dan Cara Mengatasinya. Retrieved from https://www.facebook.com/Tips-Mengesan-Jin dan Sihir-Di-DalamBadan-Dan-Cara-Mengatasi-1578285212386779/

Yaacob, R. (2018) Personal Interview. Nov 202018.

Yusof, N. (2003). Nilai Perbomohan dalam Masyarakat Melayu. Dewan Sastera. 50-52 